OPEN ACCESS

Edited by:

Thomas C. Chiles,

Boston College,

United States

Reviewed by:

Laurence Morel,

University of Florida,

United States

Wenxia Song,

University of Maryland,

College Park, United States

*Correspondence: David A. Fruman dfruman@uci.edu

Specialty section: This article was submitted to B Cell Biology,

a section of the journal

Frontiers in Immunology

Received: 30 November 2016 Accepted: 12 June 2017

Published: 30 June 2017

Citation:

Chiu H, Mallya S, Nguyen P, Mai A, Jackson LV, Winkler DG, DiNitto JP, Brophy EE, McGovern K, Kutok JL and Fruman DA (2017) The Selective

Phosphoinoside-3-Kinase p1108

Inhibitor IPI-3063 Potently

Suppresses B Cell Survival,

Proliferation, and Differentiation.

Front. Immunol. 8:747.

doi: 10.3389/fimmu.2017.00747

\section{The Selective Phosphoinoside- 3-Kinase p1108 Inhibitor IPI-3063 Potently Suppresses B Cell Survival, Proliferation, and Differentiation}

\author{
Honyin Chiu', Sharmila Mallya ${ }^{1}$, Phuongthao Nguyen ${ }^{1}$, Annie Mai', Leandra V. Jackson ${ }^{1}$, \\ David G. Winkler², Jonathan P. DiNitto², Erin E. Brophy ${ }^{2}$, Karen McGovern ${ }^{2}$, \\ Jeffery L. Kutok ${ }^{2}$ and David A. Fruman ${ }^{1 *}$ \\ 'Department of Molecular Biology and Biochemistry, University of California, Irvine, Irvine, CA, United States, \\ ${ }^{2}$ Infinity Pharmaceuticals, Inc., Cambridge, MA, United States
}

The class I phosphoinoside-3-kinases (PI3Ks) are important enzymes that relay signals from cell surface receptors to downstream mediators driving cellular functions. Elevated PI3K signaling is found in B cell malignancies and lymphocytes of patients with autoimmune disease. The $\mathrm{p} 110 \delta$ catalytic isoform of PI3K is a rational target since it is critical for B lymphocyte development, survival, activation, and differentiation. In addition, activating mutations in PIK3CD encoding p1108 cause a human immunodeficiency known as activated PI3K delta syndrome. Currently, idelalisib is the only selective p1108 inhibitor that has been FDA approved to treat certain B cell malignancies. p110 inhibitors can suppress autoantibody production in mouse models, but limited clinical trials in human autoimmunity have been performed with PI3K inhibitors to date. Thus, there is a need for additional tools to understand the effect of pharmacological inhibition of PI3K isoforms in lymphocytes. In this study, we tested the effects of a potent and selective 11108 inhibitor, IPI-3063, in assays of B cell function. We found that IPI-3063 potently reduced mouse B cell proliferation, survival, and plasmablast differentiation while increasing antibody class switching to $\lg \mathrm{G} 1$, almost to the same degree as a panPI3K inhibitor. Similarly, IPI-3063 potently inhibited human B cell proliferation in vitro. The $\mathrm{p} 110 \gamma$ isoform has partially overlapping roles with $\mathrm{p} 110 \mathrm{\delta}$ in B cell development, but little is known about its role in B cell function. We found that the p110 $\gamma$ inhibitor AS-252424 had no significant impact on B cell responses. A novel dual p1108/ $\gamma$ inhibitor, IPI-443, had comparable effects to $\mathrm{p} 110 \delta$ inhibition alone. These findings show that $\mathrm{p} 110 \delta$ is the dominant isoform mediating B cell responses and establish that IPI-3063 is a highly potent molecule useful for studying p1108 function in immune cells.

Keywords: phosphoinoside-3-kinase, lipid kinase, B cell survival, B cell proliferation, B cell differentiation

\section{INTRODUCTION}

Phosphoinoside-3-kinase (PI3K) enzymes are lipid kinases that produce 3'-phosphorylated phosphoinositides, which act as second messengers to relay signals from cell-surface receptors to downstream mediators. The class I PI3Ks produce phosphatidylinositol-3,4,5-triphosphate ( $\left.\mathrm{PIP}_{3}\right)$ that recruits cytoplasmic proteins to the membrane to drive downstream signaling responses. 
Class IA PI3Ks are heterodimers composed of two subunits, a regulatory subunit (p85) and one of three catalytic subunits (p110 $\alpha, \mathrm{p} 110 \beta, \mathrm{p} 110 \delta$ ). The class IB PI3K is composed of unique regulatory subunits (p101 or p84) with the catalytic subunit p $110 \gamma$. Whereas $\mathrm{p} 110 \alpha$ and $\mathrm{p} 110 \beta$ are ubiquitously expressed, $\mathrm{p} 110 \delta$ and $\mathrm{p} 110 \gamma$ expression is mainly restricted to leukocytes. The importance of PI3K activation in various cancers has led to development of many small molecule PI3K inhibitors targeting individual isoforms or subgroups (1).

Elevated PI3K signaling is commonly detected in malignant $B$ cells and in peripheral lymphocytes from patients with antibody-driven autoimmune diseases like lupus (2). Both genetic and pharmacological studies have implicated p110 $\delta$ to be critical for B lymphocyte development, survival, activation, and differentiation (3-5). Moreover, activating mutations in PIK3CD encoding p110 $\delta$ cause a human immunodeficiency known as activated PI3K delta syndrome (APDS), which is associated with chronically activated lymphocytes that undergo apoptosis or senescence $(6,7)$. Therefore, p110 $\delta$ has been extensively studied as a potential target for treating B cell malignancies, B cell-mediated autoimmune diseases, and potentially APDS. Impressive responses in clinical trials of idelalisib (previously known as GS-1101 or CAL-101) led to FDA approval of this drug for treatment of certain B cell malignancies (8).

Other $\mathrm{p} 110 \delta$ inhibitors have shown activity in animal models of autoimmunity. For example, IC87114 reduced autoantibody production in a rat model of collagen-induced arthritis (9). Another recently developed p110ठ inhibitor, AMG319, reduced $\mathrm{KLH}$-specific IgM and IgG production in vivo (10) while duvel-

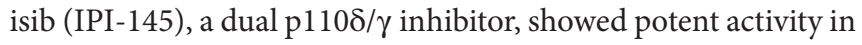
reducing inflammation in collagen-induced arthritis, ovalbumininduced asthma, and systemic lupus erythematosus rodent models (11). Currently, however, there are no approved treatments targeting $\mathrm{p} 110 \delta$ in B-cell-mediated autoimmune diseases. Additional $\mathrm{p} 110 \delta$ inhibitors with high potency and selectivity are needed as research tools for B cell biology and as potential lead compounds for B cell-driven diseases. Characterizing the effects of isoform-selective PI3K inhibitors on normal B cell function will provide insight toward finding effective therapeutic windows that can target B cell malignancies while maintaining effective host defense and may justify clinical exploration of these inhibitors in treating B cell-mediated autoimmune disease.

Previous studies have demonstrated that p110 $\delta$ is not the only PI3K isoform that contributes to B cell function. We used isoform-selective compounds to show that acute inhibition of either $\mathrm{p} 110 \alpha$ or $\mathrm{p} 110 \beta$ partially reduce signaling and functional

TABLE 1 | Summary of IC ${ }_{50}$ values for IPI-3063 and IPI-443 using purified enzymes.

\begin{tabular}{lcc}
\hline Phosphoinoside-3-kinase isoform & \multicolumn{2}{c}{ Biochemical IC $\mathbf{5 0}_{\mathbf{0}}, \mathbf{n M}(\boldsymbol{n})$} \\
\cline { 2 - 3 } & IPI-3063 & IPI-443 \\
\hline p110 $\alpha$ & $1,171 \pm 533(6)$ & $990 \pm 695(6)$ \\
p110 & $1,508 \pm 624(5)$ & $4,005 \pm 2,563(6)$ \\
p1108 & $2.5 \pm 1.2(5)$ & $6.3 \pm 3.2(6)$ \\
p110 $\gamma$ & $2,187 \pm 1,529(4)$ & $23.4 \pm 12.3(6)$
\end{tabular}

responses in activated B cells (12). Genetic analysis has shown partially overlapping roles of $\mathrm{p} 110 \delta$ and $\mathrm{p} 110 \alpha$ in B cell development (13). Little is known about the role of the class IB isoform p110 $\gamma$ in B cells. In T cells, p110 $\gamma$ plays a role in early development and is important for trafficking of activated effector cells $(14,15)$. One study reported that mice lacking both $\mathrm{p} 110 \delta$ and p110 $\gamma$ had greater defects in B cell survival and proliferation compared to $110 \delta$ knockout alone (16). The effects of chemical p110 $\gamma$ inhibition on B cell function have not been reported.

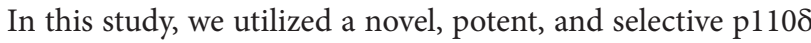
inhibitor, IPI-3063 (Table 1) that has good pharmacokinetics in mice (11). Here, we tested the effects of IPI-3063 on mouse $B$ cell survival, proliferation, and differentiation. We found that IPI-3063 is highly potent, modulating B cell responses at low nanomolar concentrations to an extent similar to a pan-PI3K inhibitor. In contrast, a selective chemical inhibitor of p110 $\gamma$ had no effect in various assays of $\mathrm{B}$ cell function. We also tested a novel

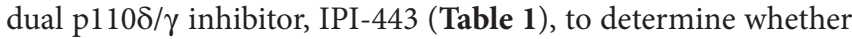
p110 $\gamma$ inhibition increases the effects beyond blockade of $\mathrm{p} 110 \delta$

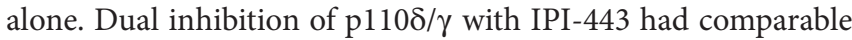
effects to IPI-3063 on B cell function. These results confirm that p110 is the dominant isoform that mediates $B$ cell responses to diverse stimuli and establish that IPI-3063 is a highly potent molecule to probe $110 \delta$ function in immune cells.

\section{RESULTS}

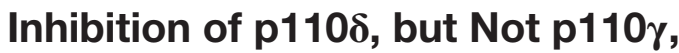 Reduces p-AKT in Activated Mouse B Cells}

IPI-3063 is a p110 selective compound with an $\mathrm{IC}_{50}=0.1 \mathrm{nM}$ in p1108-specific cell-based assays and cellular $\mathrm{IC}_{50}$ values for the other class I PI3K isoforms are at least 1,000-fold higher (Table 2) (11). IPI-443 is a selective $\mathrm{p} 110 \delta / \gamma$ dual inhibitor with a cellular $\mathrm{IC}_{50}=0.29 \mathrm{nM}$ for $\mathrm{p} 110 \delta$ and $\mathrm{IC}_{50}=7.1 \mathrm{nM}$ for $\mathrm{p} 110 \gamma$. IPI-443 activity for $\mathrm{p} 110 \alpha$ and $\mathrm{p} 110 \beta$ is $>600$-fold less potent

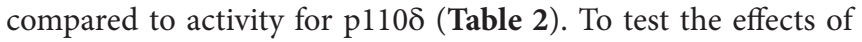
p110 $\gamma$ inhibition, we used AS-252424 compound with a biochemical $\mathrm{IC}_{50}=30 \mathrm{nM}$ for $\mathrm{p} 110 \gamma$ (17). We assessed the effects of both IPI-3063 and IPI-443 on PI3K activity in mouse primary B cells stimulated with $\alpha \operatorname{IgM}+$ IL-4, by evaluating phosphorylation of $\mathrm{AKT}$ at the serine 473 residue (Figures $\mathbf{1 A}, \mathbf{C}$ ) as well as the phosphorylation of ERK1/2 on Thr202/Tyr204 residues (Figures 1B,C). Cells were treated with a pan-PI3K inhibitor GDC-0941 or with various concentrations of IPI-3063 or IPI-443,

TABLE 2 | Summary of $\mathrm{IC}_{50}$ values for IPI-3063 and IPI-443 in isoform-specific cell-based assays.

\begin{tabular}{|c|c|c|}
\hline \multirow[t]{2}{*}{ Phosphoinoside-3-kinase isoform } & \multicolumn{2}{|c|}{ Cellular $\mathrm{IC}_{50}, \mathrm{nM}(n)$} \\
\hline & IPI-3063 & IPI-443 \\
\hline $\mathrm{p} 110 \alpha$ & $1,901 \pm 1,318(4)$ & $901.8 \pm 62.4(3)$ \\
\hline $\mathrm{p} 110 \beta$ & $102.8 \pm 35.7(4)$ & $185.2 \pm 17.2(3)$ \\
\hline p1108 & $0.1 \pm 0.01$ & $0.29 \pm 0.03$ \\
\hline $\mathrm{p} 110 \gamma$ & $418.8 \pm 117.2(2)$ & $7.1 \pm 0.5(3)$ \\
\hline
\end{tabular}



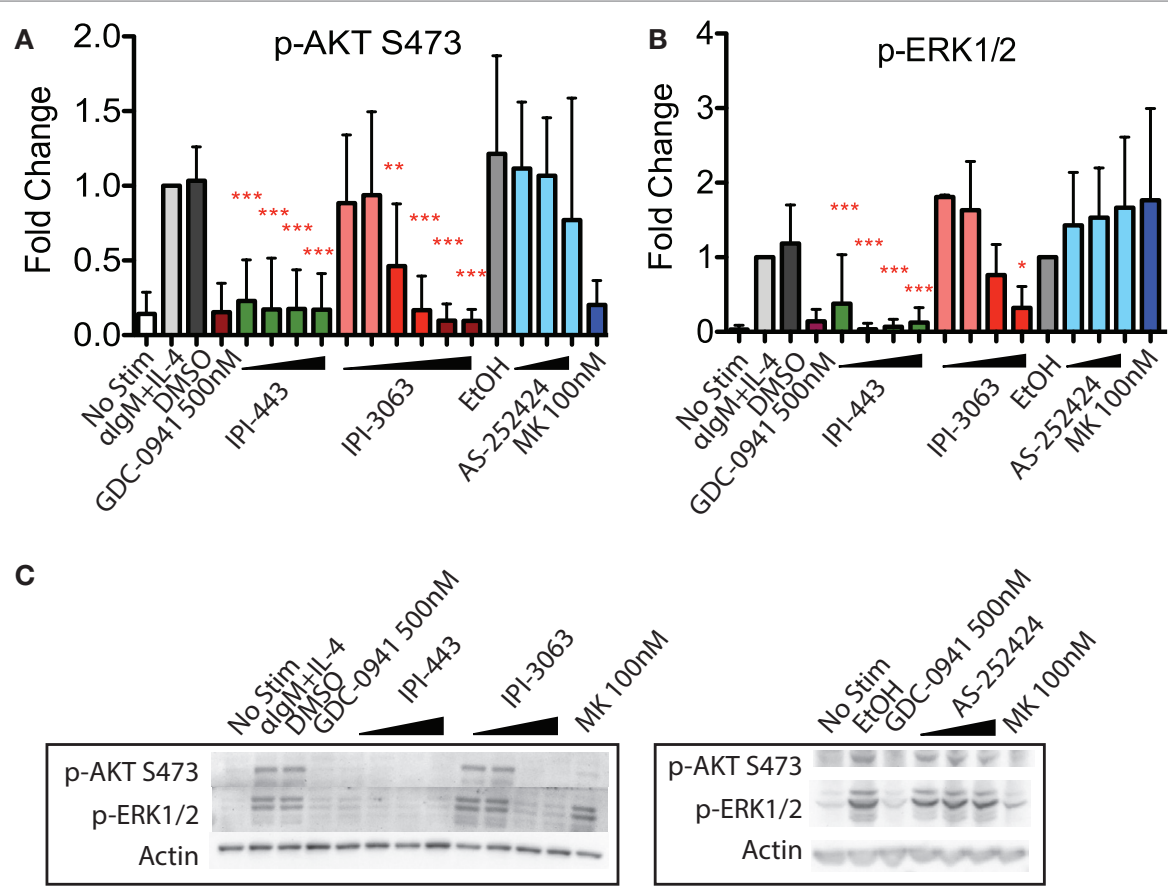

FIGURE 1 | Inhibition of p1108, but not p110 $\gamma$, reduces p-AKT and p-ERK1/2 in $\alpha$ lgM + IL-4 stimulated mouse B cells. Purified B cells were pretreated with inhibitors as indicated for $30 \mathrm{~min}$ then activated with $5 \mu \mathrm{g} / \mathrm{mL} \alpha \mathrm{gM}+10 \mathrm{ng} / \mathrm{mL}$ interleukin-4 (IL-4) for $1 \mathrm{~h}$ before harvest for western blot. (A,B) Concentrations used were $1 \mathrm{nM}, 10 \mathrm{nM}, 100 \mathrm{nM}, 1 \mu \mathrm{M}$ for IPI-443 and 0.01, 0.1, 1, 10, 30, $100 \mathrm{nM}$ for IPI-3063. AS252424 concentrations were $100 \mathrm{nM}, 300 \mathrm{nM}$, and $1 \mu \mathrm{M}$, and GDC-0941 was at 500 nM. (B,C) Concentrations of IPI-3063 used to measure p-ERK1/2 were 0.01, 0.1, 1, and 10 nM. For the graphs in panels (A,B), data were normalized to the stimulated, DMSO $0.1 \%$ condition $\left({ }^{\star} P<0.05\right.$, ${ }^{\star \star} P<0.001,{ }^{\star \star \star} P<0.0001$ one-way ANOVA with Newman-Keuls multiple comparison test).

or DMSO $(0.1 \%)$ as the diluent control. Separate cultures were treated with the p110 $\gamma$ inhibitor AS-252424 or its diluent control (0.1\% EtOH). MK-2206, an AKT inhibitor, which also reduces AKT S473 phosphorylation, was also used as a control to show ERK1/2 phosphorylation is independent of AKT activity. The p110 inhibitor, IPI-3063, was very potent in reducing p-AKT (significant effect at $1 \mathrm{nM}$ ) while the p110 $\gamma$ inhibitor, AS-252424, had no significant effect on p-AKT signaling. IPI-3063 also reduced p-ERK1/2 with a significant effect at $10 \mathrm{nM}$, whereas

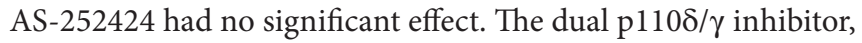
IPI-443, was also very potent in decreasing phosphorylation of AKT, with significant effects observed using concentrations as low as $1 \mathrm{nM}$, which are in the range where p110 $\delta$ is targeted selectively. These data indicate that both inhibitors are very potent in reducing PI3K signaling output while p110 $\gamma$ inhibition did not have a significant effect. B cells stimulated with LPS showed similar results with p-AKT (Figure S1 in Supplementary Material); however, LPS did not induce ERK1/2 phosphorylation (data not shown). AS-252424 caused dose-dependent inhibition of AKT phosphorylation in bone marrow-derived myeloid cells stimulated with macrophage colony stimulating factor, confirming that this compound inhibits PI3K $\gamma$ activity in cells (data not shown).

\section{IPI-3063 Potently Inhibits B Cell Survival and Proliferation}

To assess survival, purified mouse B cells were incubated for $48 \mathrm{~h}$ in either B-cell activating factor (BAFF) or interleukin-4 (IL-4) with various concentrations of IPI-3063 and IPI-443. The results showed that both IPI-3063 and IPI-443 reduced BAFF-dependent survival in a dose-dependent manner, approaching the effect of GDC-0941 (Figure 2). The selective PI3K inhibitor IPI-3063 was very potent, achieving a significant decrease in B cell survival when present at $10 \mathrm{nM}$. IPI-443 significantly decreased survival when added at $1 \mathrm{nM}$. The p110 $\gamma$ inhibitor AS-252424 had no significant effect on survival. Cells incubated with IL-4 showed similar trends.

Next, we evaluated the effects of PI3K inhibitors on B cell proliferation. We stimulated CFSE-stained cells with $\alpha \operatorname{IgM}+\mathrm{IL}-4$ or with LPS for $72 \mathrm{~h}$, or with $\alpha \mathrm{CD} 40+\mathrm{IL}-4$ or LPS + IL- 4 for $96 \mathrm{~h}$. Cells were treated with vehicle or GDC-0941, IPI-3063, IPI-443, or AS-252424 at various concentrations. Histograms of CFSE fluorescence in the cells show that IPI-3063 blocked proliferation in $\alpha$-IgM + IL- 4 stimulated B cells at the lowest concentration tested (1 nM) (Figure 3A). IPI-443 caused a dose-dependent decrease in proliferation, whereas AS-252424 had no effect. We measured the total number of divided cells over multiple experiments and found that IPI-3063 significantly reduced cell accumulation at all concentrations tested (Figure 3B). IPI-443 had a dose-dependent effect starting at $1 \mathrm{nM}$, with similar effects in LPS-stimulated B cells (Figures 3B,C). In B cells stimulated with LPS + IL-4, the inhibitors had similar trends, but with greater variability (Figure 3D). The inhibitors did not affect B cell proliferation following stimulation with $\alpha$-CD $40+$ IL-4 (Figure 3E), consistent with previous data showing $\mathrm{PI} 3 \mathrm{~K}$-independent proliferation under these conditions (3). We also measured percent 

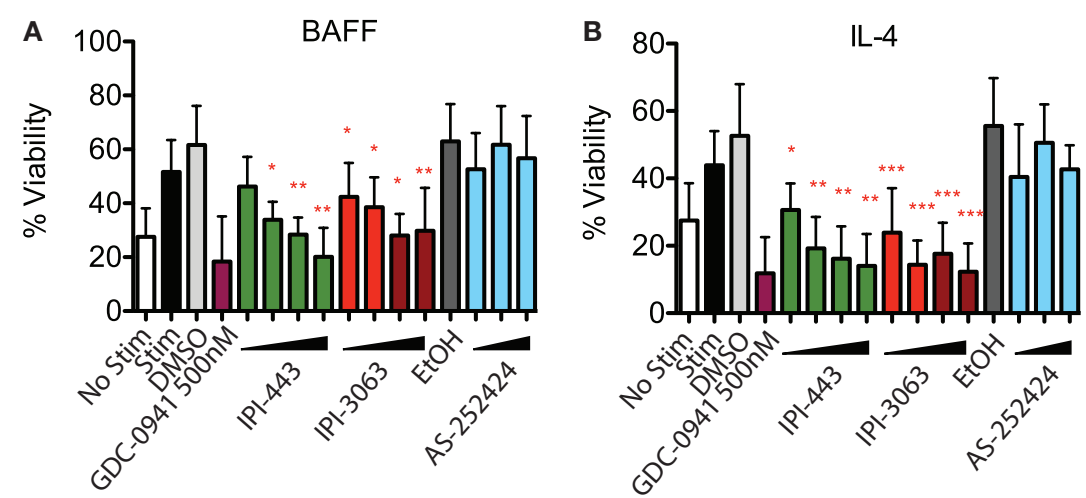

FIGURE 2 | IPI-3063 potently inhibits mouse B cell survival. Total splenocytes were pretreated with inhibitors as indicated, then cultured with 10 ng/mL IL-4 (A) or $60 \mathrm{ng} / \mathrm{mL}$ of BAFF (B) for $48 \mathrm{~h}$. Concentrations used were $1 \mathrm{nM}, 10 \mathrm{nM}, 100 \mathrm{nM}, 1 \mu \mathrm{M}$ for IPI-443 and 1, 10, 30, 100 nM for IPI-3063. AS252424 concentrations were $100 \mathrm{nM}, 300 \mathrm{nM}$, and $1 \mu \mathrm{M}$, and GDC-0941 was at $500 \mathrm{nM}$. \% viability was calculated by measuring \% of B220+7AAD- cells. Samples were collected by time. $\left({ }^{\star} P<0.05,{ }^{\star \star} P<0.001,{ }^{\star \star \star} P<0.0001\right.$ one-way ANOVA with Newman-Keuls multiple comparison test).

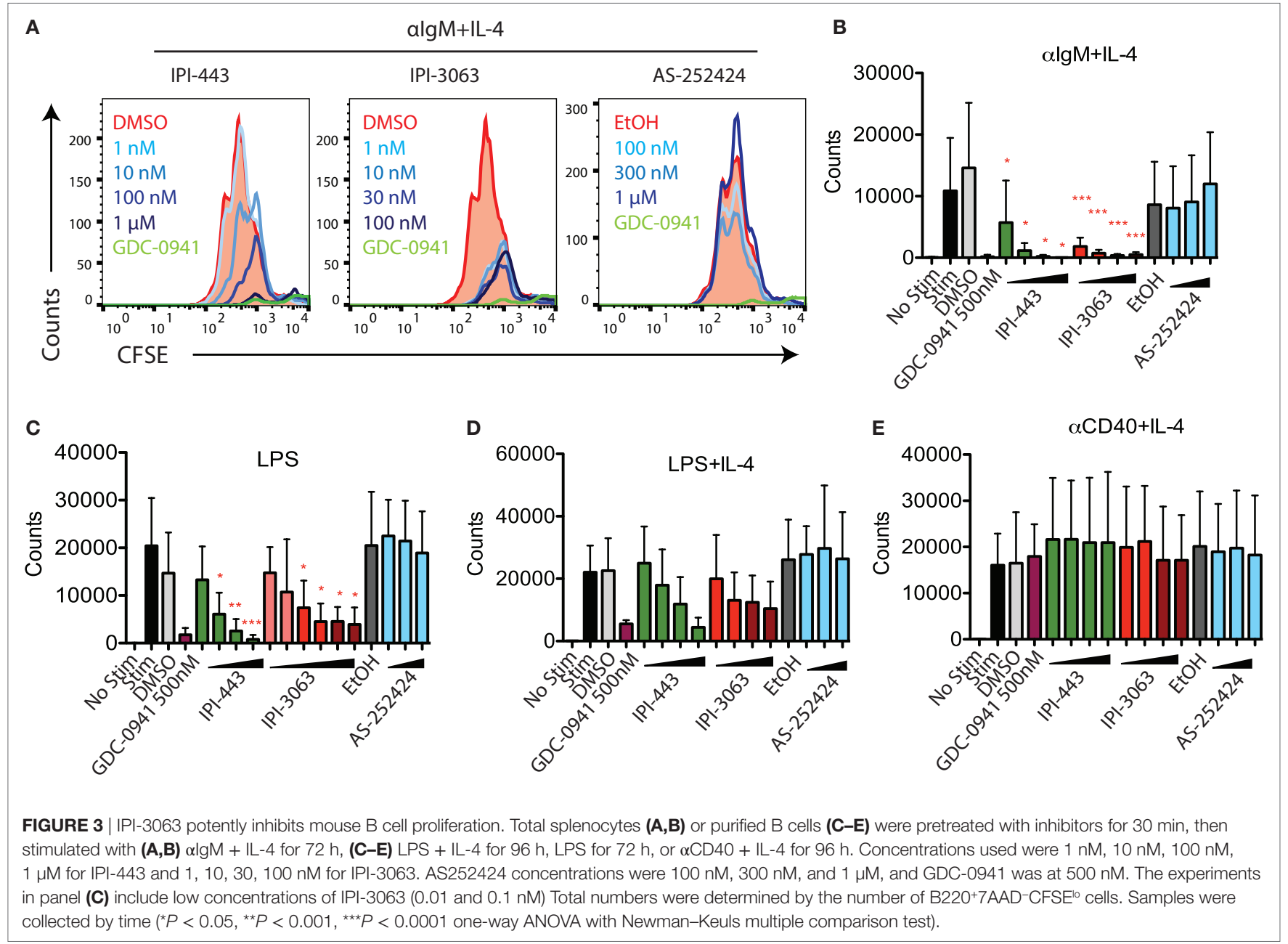

of divided cells in these conditions (Figure S2 in Supplementary

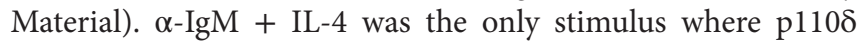
inhibition significantly reduced the percentage of cells dividing.
This analysis also showed that combined inhibition of $\mathrm{p} 110 \delta / \gamma$ by IPI-443 at $1 \mu \mathrm{M}$ reduced the percentage of divided cells more than inhibition of p $110 \delta$ only. Overall, these experiments establish that 
the selective p110 $\delta$ inhibitor IPI-3063 is a very potent inhibitor of $\mathrm{B}$ cell survival and proliferation in vitro. In addition, selective $\mathrm{p} 110 \gamma$ inhibition alone had no effect on B cell survival or proliferation.

We also tested the effects of these inhibitors on human B cell proliferation stimulated with human CD40L + anti-human IgM/ $\mathrm{IgG}+\mathrm{hIL}-2$ + hIL-21. We stimulated CFSE-stained human $\mathrm{B}$ cells for $120 \mathrm{~h}$ in the presence of GDC-0941, IPI-3063, IPI-443, or AS-252424 at various concentrations. Histograms of CFSE fluorescence in the cells show that IPI-3063 blocked proliferation at $1 \mathrm{nM}$ (Figure 4A). IPI-443 caused a dose-dependent decrease in proliferation, whereas AS-252424 had no effect. We measured the total number of divided cells and the percent divided over multiple experiments and found that IPI-3063 significantly reduced proliferation starting at $1 \mathrm{nM}$ (Figures 4B,C). IPI-443 also had a dose-dependent effect starting at $1 \mathrm{nM}$ (Figures 4B,C). These experiments extend our findings by showing that, similar to mouse B cells, human B cells treated with the selective p110 inhibitor IPI-3063 have markedly reduced ability to proliferate in vitro. In addition, selective $\mathrm{p} 110 \gamma$ inhibition also did not impair human B cell proliferation.

\section{IPI-3063 Potently Promotes Mouse B Cell Antibody Switching and Inhibits Plasmablast Differentiation}

Studies with p1108 inhibitors have shown that low PI3K signaling in B cells promotes antibody class switch recombination (CSR) and decreases differentiation into plasmablasts that secrete low-affinity $\operatorname{IgM}(18,19)$. Activation of mouse primary B cells with $\alpha \mathrm{CD} 40+$ IL- 4 or LPS + IL- 4 both induce IgG1 class switching while treatment with LPS alone induces the plasmablast differentiation fate (Figure 5A). In B cells stimulated with $\alpha \mathrm{CD} 40+\mathrm{IL}-4$, IPI-3063 increased the percentage of B220+ cells switching to IgG1 starting at $1 \mathrm{nM}$ and approached the effect of GDC-0941 (Figure 5B). IPI-443 followed a similar trend, significantly increasing IgG1 switching at concentrations of $1 \mathrm{nM}$ or higher, while p110 $\gamma$ inhibitor AS-252424 had no effect (Figure 5B). In cells activated with LPS + IL-4, none of the inhibitors significantly increased \% IgG1 ${ }^{+}$(Figure 5C).

We also evaluated plasmablast differentiation and IgM secretion in LPS-stimulated cells (Figure 5D). IPI-3063 potently decreased plasmablast differentiation starting at $1 \mathrm{nM}$, as

A hCD40L + anti-human IgM/lgG + hIL-2 + hIL-21
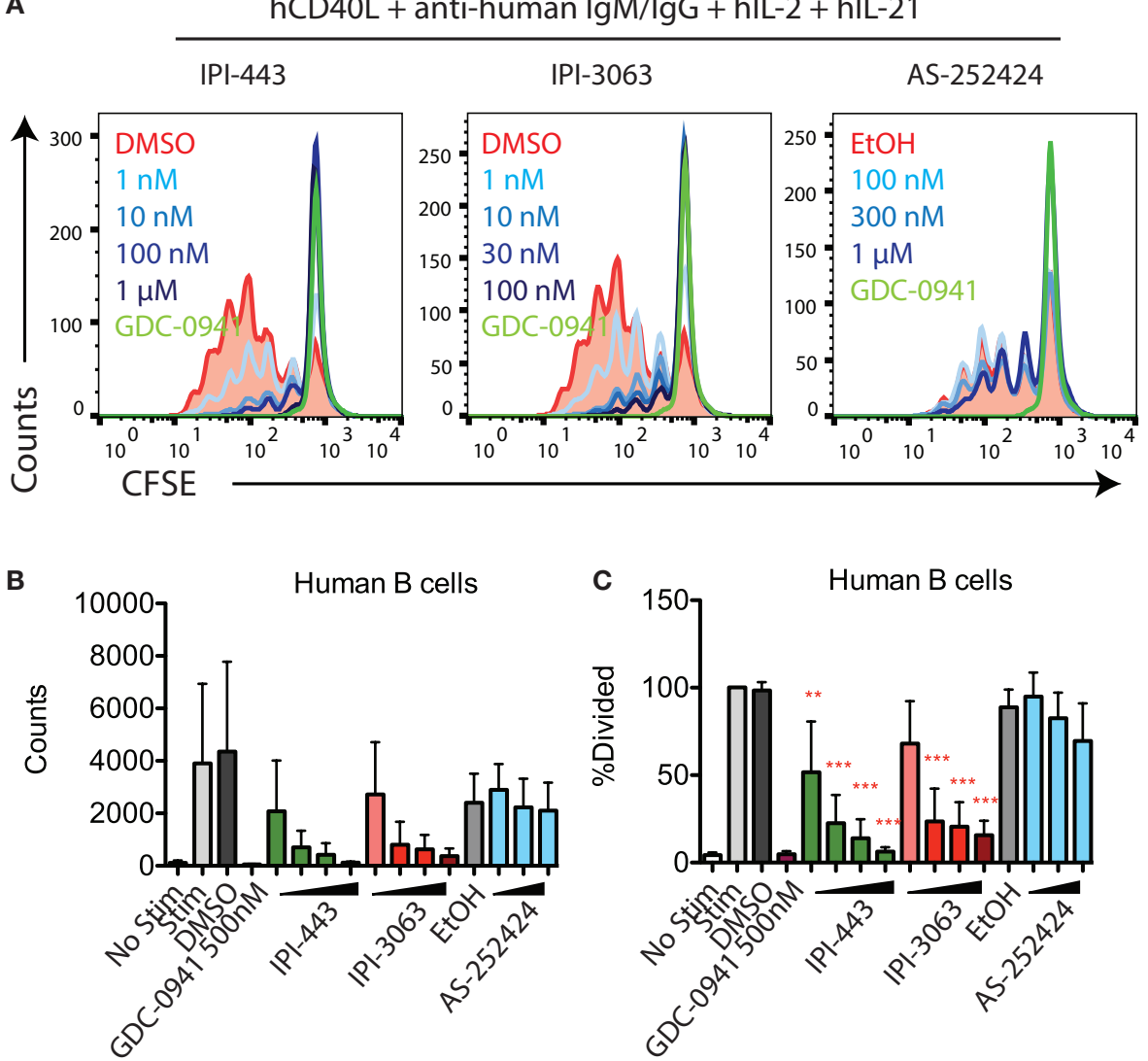

FIGURE 4 | IPI-3063 potently inhibits human B cell proliferation. (A-C) Purified human B cells were pretreated with inhibitors for 30 min, then stimulated with human $\mathrm{CD} 40 \mathrm{~L}+$ anti-human IgM/IgG + human IL-2 + human IL-21 for $120 \mathrm{~h}$. Concentrations used were $1 \mathrm{nM}, 10 \mathrm{nM}, 100 \mathrm{nM}$, and $1 \mu \mathrm{M}$ for IPI-443, and 0.1, 1, 10, and $100 \mathrm{nM}$ for IPI-3063. AS252424 concentrations were $100 \mathrm{nM}, 300 \mathrm{nM}$, and $1 \mu \mathrm{M}$, and GDC-0941 was at $500 \mathrm{nM}$. Total numbers and percent divided were determined by the number of CD19+7AAD-CFSE ${ }^{10}$ cells. Samples were collected by time $\left({ }^{\star} P<0.05,{ }^{* *} P<0.001,{ }^{* * *} P<0.0001\right.$ one-way ANOVA with NewmanKeuls multiple comparison test). 

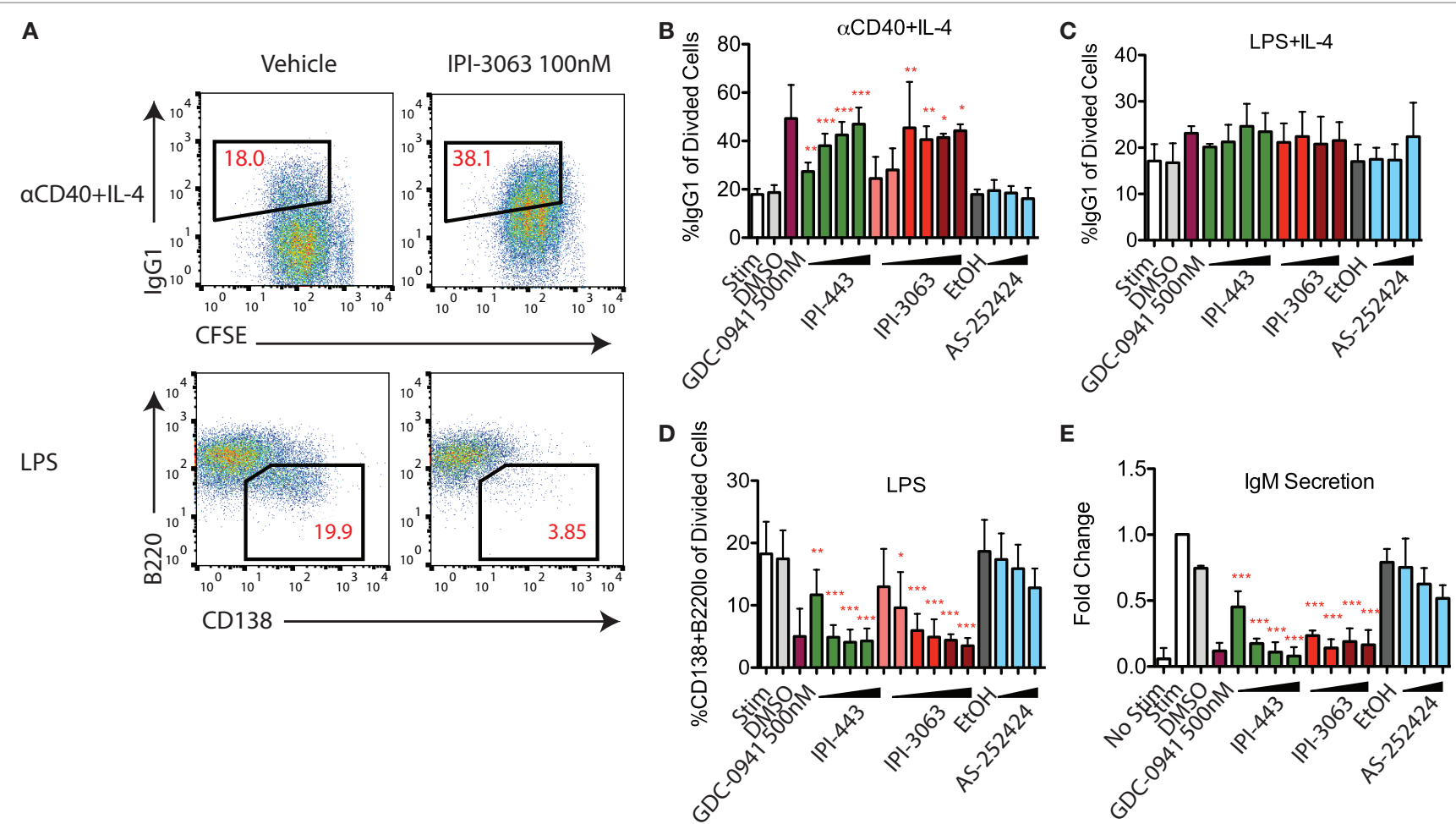

FIGURE 5 | IPI-3063 potently promotes mouse B cell antibody switching and inhibits plasmablast differentiation. Purified B cells were pretreated with inhibitors, then stimulated with $\alpha \mathrm{CD} 40+\mathrm{IL}-4$ (B) or LPS + IL-4 (C) for $96 \mathrm{~h}$ to induce switching to lgG1 or LPS (D) for $72 \mathrm{~h}$ to induce plasmablast differentiation. Class switching to IgG1 was measured by the 7AAD-CFSE ${ }^{\circ} \mathrm{B} 22 \mathrm{O}^{+} \mathrm{IgG} 1^{+}$cells [(A), upper panels]. Plasmablast percentages were calculated by \% $7 \mathrm{AAD}-\mathrm{CFSE}{ }^{\circ} \mathrm{CD} 138^{+} \mathrm{B} 22 \mathrm{O}^{\circ \circ}$ population [(A), lower]. Supernatant was harvested (E) for IgM ELISA. Concentrations used were $1 \mathrm{nM}, 10 \mathrm{nM}, 100 \mathrm{nM}, 1 \mu \mathrm{M}$ for IPI-443 and 1, 10, $30,100 \mathrm{nM}$ for IPI-3063. Low concentrations of IPI-3063 were 0.01 and $0.1 \mathrm{nM}$ (D). AS252424 concentrations were $100 \mathrm{nM}, 300 \mathrm{nM}$, and $1 \mu \mathrm{MM}$, and GDC-0941 was at $500 \mathrm{nM}$. Samples were collected by time $\left({ }^{*} P<0.05,{ }^{* *} P<0.001,{ }^{* \star *} P<0.0001\right.$ one-way ANOVA with Newman-Keuls multiple comparison test).

measured by the percentage of the $\mathrm{CD} 138^{+} \mathrm{B} 220^{\text {lo }}$ population. IPI-443 also caused a dose-dependent decrease starting at $1 \mathrm{nM}$. In cells treated with IPI-3063 or IPI-443, the highest concentrations inhibited plasmablast differentiation to the same degree as GDC-0941. Measuring IgM secretion by ELISA showed similar trends (Figure 5E). In the plasmablast and IgM secretion assays, the p110 $\gamma$ inhibitor AS-252424 caused no significant effect.

Overall, these results show that IPI-3063 is very potent at increasing B cell antibody class switching to IgG1 in B cells stimulated with $\alpha \mathrm{CD} 40+$ IL-4, while potently reducing plasmablast differentiation in cells stimulated with LPS. Combined inhibition of $\mathrm{p} 110 \delta / \gamma$ by IPI-443 had a similar effect that was not significantly greater than inhibition of p $110 \delta$ only, and importantly, p110 $\gamma$-specific inhibition did not show any significant effect.

\section{DISCUSSION}

In this study, we have used novel inhibitors of $\mathrm{p} 110 \delta, \mathrm{p} 110 \delta / \gamma$, and p $110 \gamma$ to study how acute inhibition of these isoforms impacts B cell function. Consistent with previous studies $(5,18,20)$, our results show that $\mathrm{p} 110 \delta$ inhibition decreased several mouse B cell functions including survival, $\alpha \operatorname{IgM}+$ IL-4-induced proliferation, and plasmablast differentiation while increasing class switching to IgG1. We also show that these inhibitors are potent at reducing human B cell proliferation in vitro. Importantly, additional p110 $\gamma$ inhibition had little to no effect, indicating that the class IB isoform $\mathrm{p} 110 \gamma$ has a minor role in the function of mature B cells. Both IPI-3063 and IPI-443 were highly potent at inhibiting these $\mathrm{B}$ cell functions, with activity in the nanomolar ranges that achieved similar results to the pan-class I inhibitor GDC-0941.

In contrast with a previous study using genetic deletion of the

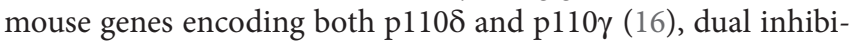
tion with IPI-443 (achieved at concentrations in the 10-1,000 nM range) did not reduce proliferation and survival more than $\mathrm{p} 110 \delta$ inhibition alone in B cells. However, Beer-Hammer et al. also showed that B cell development was impaired at the pre-pro B cell stage when both $\mathrm{p} 110 \delta / \gamma$ are deleted (16). The differences they observed in the double deleted cells compared to single p1108 deletion may be due to developmental defects. In addition, the previous study measured LPS-driven B cell proliferation in the context of total splenocytes, where myeloid cell cytokine production in response to LPS might be a confounding factor. While we did not see any effects with p110 $\gamma$ inhibition or additional effects with dual $\mathrm{p} 110 \delta / \gamma$ inhibition in our assays, these experiments only tested purified B cells in vitro and did not test the role of $\mathrm{p} 110 \gamma$ in vivo. Although B cell function is mainly $\mathrm{p} 110 \delta$ 
dependent, p110 $\gamma$ does play an important role in neutrophil, macrophage, and eosinophil recruitment (21) as well as in T cell proliferation and cytokine production (22) and T cell migration $(15,23,24)$. Thus, pharmacological inhibition of $\mathrm{p} 110 \gamma$ in vivo could indirectly affect B cell function.

Small molecule inhibitors that are selective for single PI3K isoforms or pairs of isoforms have been highly useful in delineating the shared and distinct functions of PI3K enzymes in diverse cell types $(2,25)$. Our results show that the selective p110 inhibitor IPI-3063 and the $\mathrm{p} 110 \delta / \gamma$ dual inhibitor IPI-443 are highly potent, having effects on $\mathrm{B}$ cells at the nanomolar range in vitro. These data demonstrate that these inhibitors will be useful tools in studying the function of $\mathrm{p} 110 \delta / \gamma$ or $\mathrm{p} 110 \delta$ alone. Additional studies will be required to determine whether these or similar compounds will be suitable in treating patients with diseases driven by B cells or other immune cell types in which

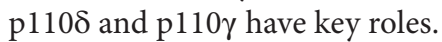

\section{MATERIALS AND METHODS}

\section{PI3K Enzymatic Assay}

Human recombinant PI3K- $\alpha$ (cat. no. $14-602-K),-\beta$ (cat. no. $14-603-\mathrm{K}),-\delta$ (cat. no. $14-604-\mathrm{K})$, and $-\gamma$ (cat. no. $14-558-\mathrm{K}$ ) were purchased from Millipore. Phosphatidylinositol 4,5 bis phosphate (diC8-PtdIns(4,5)P2) was purchased from Avanti Polar Lipids, Inc. PI3K- $\alpha, \beta$, and $\delta$ are heterodimers consisting of full length $\mathrm{p} 110 \alpha, \mathrm{p} 110 \beta$, or $\mathrm{p} 110 \delta$ catalytic subunit and the $\mathrm{p} 85 \alpha$ regulatory subunit. $\mathrm{PI} 3 \mathrm{~K}-\gamma$ is a monomer of the $\mathrm{p} 110 \gamma$ catalytic subunit. Samples of kinase $(10 \mathrm{nM}-\alpha, \beta$, and $\delta ; 20 \mathrm{nM}-\gamma)$ were incubated with inhibitor for $30 \mathrm{~min}$ at room temperature in reaction buffer (15 mM HEPES pH 7.4, $20 \mathrm{mM} \mathrm{NaCl}, 1$ mM EGTA, $0.02 \%$ Tween $20,10 \mathrm{mM} \mathrm{MgCl} 2,0.2 \mathrm{mg} / \mathrm{mL}$ bovine- $\gamma$-globulins) followed by addition of ATP/diC8-PtdIns(4,5)P2 mixture to give final concentrations of $3 \mathrm{mM}$ ATP and $500 \mu \mathrm{M}$ diC8-PtdIns $(4,5)$ $\mathrm{P} 2$. Reactions were incubated at room temperature for $2 \mathrm{~h}$, with PI3K activity assessed via the Promega ADP-Glo Max assay kit (cat. no. V7002) according to the manufacturer's instruction. Plates were read on Envision plate reader in luminescence mode.

\section{pAKT S473 ELISA Assay}

Phospho-Akt1 (S473) sandwich ELISA antibody kit (Cell Signaling Technology, cat. no. 7143) was utilized to analyze pAKT signal in cells as described previously by Winkler et al. (11) (for data see Table 2). Briefly, SKOV3 and 786.0 cells were seeded into 96-well cell culture-graded plates at a density of two million per $200 \mu \mathrm{l}$ culture media per well. Raji and Raw264.7 were seeded at the same density in FBS-free media. After overnight incubation at $5 \% \mathrm{CO}_{2}$ and $37^{\circ} \mathrm{C}$, the cells were treated with inhibitor for $30 \mathrm{~min}$. Raji cells were stimulated with $10 \mu \mathrm{g} / \mathrm{mL}$ anti-human IgM (Jackson ImmunoResearch) for $30 \mathrm{~min}$ and Raw264.7 cells with $25 \mathrm{nM} \mathrm{C5a}$ (RnD Systems) for $3 \mathrm{~min}$ in the presence of inhibitor. SKOV3 and 786.0 cells were not stimulated. Medium was then aspirated and $50 \mu \mathrm{L} /$ well of ice-cold lysis buffer was added. pAKT level was determined according to the manufacturer's instruction.

\section{Mice and Reagents}

C57BL/6 mice were bred at the University of California, Irvine, and used at between 6 and 12 weeks of age. All animals were studied in compliance with protocols approved by the Institutional Animal Care and Use Committee of the University of California, Irvine.

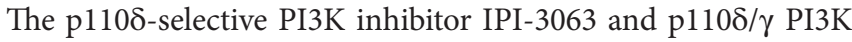
inhibitor IPI-443 were synthesized at Infinity Pharmaceuticals. These compounds and the pan-PI3K class I inhibitor GDC-0941 (LClaboratories) were dissolved in DMSO. The p110 $\gamma$ PI3K inhibitor AS-252424 (Chemdea) was dissolved in ethanol. Inhibitors were included throughout the indicated cell treatment periods.

\section{Mouse B Cell Culture}

Mouse splenic B cells were purified by negative selection (eBioscience Magnisort Mouse B cell enrichment kit). B-cell purity was $>95 \%$ as measured by FACS analysis (FACSCalibur and CellQuest software; BD Biosciences) using anti-B220 antibody (BioLegend). Purified B cells were seeded at a final concentration of 0.5 or $0.25 \times 10^{6}$ cells $/ \mathrm{mL}$. For plasmablast differentiation, $\mathrm{B}$ cells were stimulated with $5 \mu \mathrm{g} / \mathrm{mL}$ LPS (Sigma) for $72 \mathrm{~h}$, and for IgG1 CSR, B cells were stimulated $5 \mu \mathrm{g} / \mathrm{mL}$ anti-CD40 (HM403) agonistic antibody (eBioscience), or $5 \mu \mathrm{g} / \mathrm{mL}$ LPS (Sigma), together with $5 \mathrm{ng} / \mathrm{mL} \mathrm{mIL-4} \mathrm{(R \& D} \mathrm{Systems)} \mathrm{for} 96 \mathrm{~h}$. All B cells were cultured in RPMI 1640 supplemented with 10\% (vol/vol) heat-inactivated FCS, $5 \mathrm{mM}$ Hepes, $2 \mathrm{mM}$ L-glutamine, $100 \mathrm{U} / \mathrm{mL}$ penicillin, $100 \mu \mathrm{g} / \mathrm{mL}$ streptomycin, $50 \mu \mathrm{M}$ 2-mercaptoethanol.

\section{Western Blotting Analysis}

Analysis was performed on western blots using ImageJ to measure mean fluorescence intensities of each band. Phospho-AKT S473 and phospho-ERK1/2 signal was normalized with actin measurements and fold change was calculated using the stimulated/no drug control.

\section{Flow Cytometry, CFSE Labeling, and Antibodies}

Before cell surface staining, cells were incubated with TruStain fcX in FACS buffer $(0.5 \%$ BSA $+0.02 \% \mathrm{NaN} 3$ in $1 \times$ HBSS $)$ to block Fc receptors for $10 \mathrm{~min}$ on ice. Staining with antibodies was subsequently performed, also with FACS buffer and on ice for $20 \mathrm{~min}$. Flow cytometry antibodies and other reagents used were as follows: B220 (RA3-6B2), IgG1 (A85-1), CD138 (281-2), and 7-Aminoactinomycin D. CFSE labeling of B cells to track proliferation was performed by resuspending cells to a concentration of $10 \times 10^{6}$ cells $/ \mathrm{mL}$ with a concentration of $2.5 \mu \mathrm{M}$ CFSE. Flow cytometric data were analyzed using FlowJo software (TreeStar).

\section{Immunoglobulin ELISA}

For cell culture ELISA to measure total IgM, supernatants from purified B cells stimulated with LPS were collected after 3 days and diluted 1:1,000 in 2\% (wt/vol) BSA in PBS. Nunc Maxisorp plates (Thermo Fisher) were coated with anti-mouse IgM (RMM-1; BioLegend) at $10 \mu \mathrm{g} / \mathrm{mL}$ in $50 \mu \mathrm{L}$ of total sample in PBS and allowed to incubate overnight at $4^{\circ} \mathrm{C}$. Diluted supernatant samples were incubated on coated plates for $1 \mathrm{~h}$ at $37^{\circ} \mathrm{C}$. HRP-conjugated rabbit anti-mouse IgM secondary antibody (Zymed) was used. 


\section{Human B Cell Culture}

Peripheral blood from normal volunteers was obtained through an Institutional Review Board-approved protocol. Peripheral blood mononuclear cells (PBMCs) were first purified from blood by density gradient centrifugation using Ficoll-Paque. Human $\mathrm{B}$ cells were then purified from PBMCs by negative selection (eBioscience Magnisort Human B cell enrichment kit). B-cell purity was increased from $4 \%$ to $>70 \%$ as measured by FACS analysis (FACSCalibur and CellQuest software; BD Biosciences) using anti-CD19 PE conjugated antibody (eBioscience). Purified $B$ cells were seeded at a final concentration of $0.1 \times 10^{6}$ cells $/ \mathrm{mL}$ and cultured with $2 \mu \mathrm{g} / \mathrm{mL}$ human CD40L (eBioscience) $+5 \mu \mathrm{g} /$ $\mathrm{mL}$ anti-human IgM/IgG (eBioscience) $+100 \mu \mathrm{g} / \mathrm{mL}$ hIL-2 (R\&D Systems $)+100 \mu \mathrm{g} / \mathrm{mL}$ hIL-21 (R\&D Systems). All B cells were cultured in RPMI 1640 supplemented with $10 \%$ (vol/vol) heatinactivated FCS, $5 \mathrm{mM}$ Hepes, $2 \mathrm{mM}$ L-glutamine, $100 \mathrm{U} / \mathrm{mL}$ penicillin, $100 \mu \mathrm{g} / \mathrm{mL}$ streptomycin, $50 \mu \mathrm{M} 2$ 2-mercaptoethanol.

\section{ETHICS STATEMENT}

Live animals (mice) were studied in compliance with protocols approved by the Institutional Animal Care and Use Committee of the University of California, Irvine.

\section{AUTHOR CONTRIBUTIONS}

DF designed research and wrote the manuscript. HC designed and performed research and wrote the manuscript. SM, PN, AM, LJ, JD, and EB designed and performed research. DW, KM, and JK designed research and wrote the manuscript.

\section{ACKNOWLEDGMENTS}

We thank Drs. Judith Varner and Megan Kaneda (UCSD) for validating the p110 $\gamma$ inhibitor. Access to normal human blood specimens was supported by the National Center for Research Resources and the National Center for Advancing Translational Sciences, National Institutes of Health, through

\section{REFERENCES}

1. Fruman DA, Rommel C. PI3K and cancer: lessons, challenges and opportunities. Nat Rev Drug Discov (2014) 13:140-56. doi:10.1038/nrd4204

2. Puri KD, Gold MR. Selective inhibitors of phosphoinositide 3-kinase delta: modulators of B-cell function with potential for treating autoimmune inflammatory diseases and B-cell malignancies. Front Immunol (2012) 3:256. doi:10.3389/fimmu.2012.00256

3. Fruman DA, Snapper SB, Yballe CM, Davidson L, Yu JY, Alt FW, et al. Impaired B cell development and proliferation in absence of phosphoinositide 3-kinase p85alpha. Science (1999) 283:393-7. doi:10.1126/science. 283.5400 .393

4. Okkenhaug K, Bilancio A, Farjot G, Priddle H, Sancho S, Peskett E, et al. Impaired $\mathrm{B}$ and $\mathrm{T}$ cell antigen receptor signaling in p110delta PI 3-kinase mutant mice. Science (2002) 297:1031-4. doi:10.1126/science. 1073560

5. Bilancio A, Okkenhaug K, Camps M, Emery JL, Ruckle T, Rommel C, et al. Key role of the p110delta isoform of PI3K in B-cell antigen and IL-4 receptor signaling: comparative analysis of genetic and pharmacologic interference
Grant UL1 TR001414. The content is solely the responsibility of the authors and does not necessarily represent the official views of the NIH.

\section{FUNDING}

The authors declare that this study received funding from Infinity Pharmaceuticals through a sponsored research agreement. Co-authors DW, KM, and JK were employees of Infinity pharmaceuticals and were involved in the study design, interpretation of data, and in writing the manuscript. HC was supported by $\mathrm{NIH}$ training grant T32-AI060573 and by a matching fellowship from the Graduate Division of the University of California, Irvine.

\section{SUPPLEMENTARY MATERIAL}

The Supplementary Material for this article can be found online at http://journal.frontiersin.org/article/10.3389/fimmu.2017.00747/ full\#supplementary-material.

FIGURE S1 | Inhibition of p1108, but not p110 $\gamma$, reduces p-AKT in LPSstimulated mouse B cells. Purified B cells were pretreated with inhibitors as indicated for $30 \mathrm{~min}$, then activated with $5 \mu \mathrm{g} / \mathrm{mL}$ LPS for $1 \mathrm{~h}$ before harvest for western blot. (A,B) Concentrations used were $1 \mathrm{nM}, 10 \mathrm{nM}, 100 \mathrm{nM}, 1 \mu \mathrm{M}$ for IPI-443 and 1, 10, 30, 100 nM for IPI-3063. AS252424 concentrations were $100 \mathrm{nM}, 300 \mathrm{nM}$, and $1 \mu \mathrm{M}$, and GDC-0941 was at $500 \mathrm{nM}$. (C) Concentrations of IPI-3063 were 0.01, 0.1, 1, and $10 \mathrm{nM}$. For the graph in panel (A), data were normalized to the stimulated, DMSO $0.1 \%$ condition $\left({ }^{\star} P<0.05,{ }^{\star \star} P<0.001\right.$,

${ }^{* \star *} P<0.0001$ one-way ANOVA with Newman-Keuls multiple comparison test).

FIGURE S2 | IPI-3063 potently inhibits mouse B cell proliferation. Total splenocytes $\mathbf{( A , B )}$ or purified B cells (C-E) were pretreated with inhibitors for $30 \mathrm{~min}$, then stimulated with (A,B) $\alpha \mathrm{lgM}+\mathrm{IL}-4$ for $72 \mathrm{~h}$ (C-E) LPS + IL-4 for $96 \mathrm{~h}$, LPS for $72 \mathrm{~h}$ or $\alpha \mathrm{CD} 40+\mathrm{IL}-4$ for $96 \mathrm{~h}$. Concentrations used were $1 \mathrm{nM}$, 10 nM, 100 nM, 1 MM for IPI-443 and 1, 10, 30, 100 nM for IPI-3063. AS252424 concentrations were $100 \mathrm{nM}, 300 \mathrm{nM}$, and $1 \mu \mathrm{M}$, and GDC-0941 was at $500 \mathrm{nM}$. The experiments in panel (C) include low concentrations of IPI-3063 (0.01 and $0.1 \mathrm{nM})$. Panel (A) shows proliferation of cells by CFSE histograms. Right peak in GDC and IPI-443 $1 \mu \mathrm{M}$-treated cells represents dead cells. Percent divided were determined by the percent of B220+7AAD-CFSElo cells and normalized to no drug treated. Samples were collected by time $\left({ }^{\star} P<0.05\right.$, ${ }^{\star \star} P<0.001,{ }^{\star \star \star} P<0.0001$ one-way ANOVA with Newman-Keuls multiple comparison test). with p110delta function in B cells. Blood (2006) 107:642-50. doi:10.1182/ blood-2005-07-3041

6. Angulo I, Vadas O, Garçon F, Banham-Hall E, Plagnol V, Leahy TR, et al. Phosphoinositide 3-kinase $\delta$ gene mutation predisposes to respiratory infection and airway damage. Science (2013) 342:866-71. doi:10.1126/science. 1243292

7. Lucas CL, Kuehn HS, Zhao F, Niemela JE, Deenick EK, Palendira U, et al. Dominant-activating germline mutations in the gene encoding the $\mathrm{PI}(3) \mathrm{K}$ catalytic subunit p110 result in T cell senescence and human immunodeficiency. Nat Immunol (2014) 15:88-97. doi:10.1038/ni.2771

8. Fruman DA, Rommel C. PI3Kס inhibitors in cancer: rationale and serendipity merge in the clinic. Cancer Discov (2011) 1:562-72. doi:10.1158/2159-8290. CD-11-0249

9. Durand CA, Hartvigsen K, Fogelstrand L, Kim S, Iritani S, Vanhaesebroeck B, et al. Phosphoinositide 3-kinase p110 delta regulates natural antibody production, marginal zone and B-1 B cell function, and autoantibody responses. J Immunol (2009) 183:5673-84. doi:10.4049/jimmunol.0900432

10. Cushing TD, Hao X, Shin Y, Andrews K, Brown M, Cardozo M, et al. Discovery and in vivo evaluation of (S)-N-(1-(7-fluoro-2-(pyridin-2-yl)quinolin-3-yl) 
ethyl)-9H-purin-6-amine (AMG319) and related PI3K inhibitors for inflammation and autoimmune disease. J Med Chem (2014) 58(1): 480-511. doi:10.1021/jm501624r

11. Winkler DG, Faia KL, Dinitto JP, Ali JA, White KF, Brophy EE, et al. PI3K- $\delta$ and PI3K- $\gamma$ inhibition by IPI-145 abrogates immune responses and suppresses activity in autoimmune and inflammatory disease models. Chem Biol (2013) 20(11) 1364-74. doi:10.1016/j.chembiol.2013.09.017

12. So L, Yea SS, Oak JS, Lu M, Manmadhan A, Ke QH, et al. Selective inhibition of phosphoinositide 3-kinase p $110 \alpha$ preserves lymphocyte function. J Biol Chem (2013) 288:5718-31. doi:10.1074/jbc.M112.379446

13. Ramadani F, Bolland DJ, Garcon F, Emery JL, Vanhaesebroeck B, Corcoran AE, et al. The PI3K isoforms p110alpha and p110delta are essential for pre-B cell receptor signaling and B cell development. Sci Signal (2010) 3:ra60. doi:10.1126/scisignal.2001104

14. Ladygina N, Gottipati S, Ngo K, Castro G, Ma JY, Banie H, et al. PI3K $\gamma$ kinase activity is required for optimal T-cell activation and differentiation. Eur J Immunol (2013) 43(12):3183-96. doi:10.1002/eji.201343812

15. Martin AL, Schwartz MD, Jameson SC, Shimizu Y. Selective regulation of CD8 effector T cell migration by the p110 gamma isoform of phosphatidylinositol 3-kinase. J Immunol (2008) 180:2081-8. doi:10.4049/ jimmunol.180.4.2081

16. Beer-Hammer S, Zebedin E, von Holleben M, Alferink J, Reis B, Dresing P, et al. The catalytic PI3K isoforms p110gamma and p110delta contribute to B cell development and maintenance, transformation, and proliferation. J Leukoc Biol (2010) 87:1083-95. doi:10.1189/jlb.0809585

17. Pomel V, Klicic J, Covini D, Church DD, Shaw JP, Roulin K, et al. Furan2-ylmethylene thiazolidinediones as novel, potent, and selective inhibitors of phosphoinositide 3-kinase gamma. J Med Chem (2006) 49:3857-71. doi:10.1021/jm0601598

18. Omori SA, Cato MH, Anzelon-Mills A, Puri KD, Shapiro-Shelef M, Calame K, et al. Regulation of class-switch recombination and plasma cell differentiation by phosphatidylinositol 3-kinase signaling. Immunity (2006) 25:545-57. doi:10.1016/j.immuni.2006.08.015

19. Limon JJ, So L, Jellbauer S, Chiu H, Corado J, Sykes SM, et al. mTOR kinase inhibitors promote antibody class switching via mTORC2 inhibition. Proc Natl Acad Sci U S A (2014) 111:E5076-85. doi:10.1073/pnas. 1407104111

20. Limon JJ, Fruman DA. Akt and mTOR in B Cell activation and differentiation. Front Immunol (2012) 3:228. doi:10.3389/fimmu.2012.00228

21. Costa C, Martin-Conte EL, Hirsch E. Phosphoinositide 3-kinase p110 $\gamma$ in immunity. IUBMB Life (2011) 63:707-13. doi:10.1002/iub.516

22. Sasaki T, Irie-Sasaki J, Jones RG, Oliveira-dos-Santos AJ, Stanford WL, Bolon B, et al. Function of PI3Kgamma in thymocyte development, T cell activation, and neutrophil migration. Science (2000) 287:1040-6. doi:10.1126/ science.287.5455.1040

23. Reif K, Okkenhaug K, Sasaki T, Penninger JM, Vanhaesebroeck B, Cyster JG. Cutting edge: differential roles for phosphoinositide 3-kinases, p110gamma and p110delta, in lymphocyte chemotaxis and homing. J Immunol (2004) 173:2236-40. doi:10.4049/jimmunol.173.4.2236

24. Thomas MS, Mitchell JS, DeNucci CC, Martin AL, Shimizu Y. The p110gamma isoform of phosphatidylinositol 3-kinase regulates migration of effector CD4 T lymphocytes into peripheral inflammatory sites. JLeukoc Biol (2008) 84:814-23. doi:10.1189/jlb.0807561

25. Hawkins PT, Stephens LR. PI3K signalling in inflammation. Biochim Biophys Acta (2015) 1851:882-97. doi:10.1016/j.bbalip.2014.12.006

Conflict of Interest Statement: DW, JD, EB, KM, and JK were employees and shareholders at Infinity Pharmaceuticals, Inc., at the time of these studies. DF previously served as a consultant for Infinity Pharmaceuticals. The other authors declare that the research was conducted in the absence of any commercial or financial relationships that could be construed as a potential conflict of interest.

Copyright (c) 2017 Chiu, Mallya, Nguyen, Mai, Jackson, Winkler, DiNitto, Brophy, McGovern, Kutok and Fruman. This is an open-access article distributed under the terms of the Creative Commons Attribution License (CC BY). The use, distribution or reproduction in other forums is permitted, provided the original author(s) or licensor are credited and that the original publication in this journal is cited, in accordance with accepted academic practice. No use, distribution or reproduction is permitted which does not comply with these terms. 